\title{
The Justiciability of the Non-Justiciable Constitutional Policy of Governance in Nigeria*
}

\author{
G.N. Okeke and C. Okeke
}

\begin{abstract}
Using legislation to make justiciable the non-justiciable policy of governance as contained in the Chapter Two of the Constitution of the Federal Republic of Nigeria (CFRN), 1999, as amended is a material contradiction. This, it is submitted, is akin to making an act of the National Assembly of Nigeria to prevail over the letters of the Constitution as enunciated in Section 6(6)(c) of the CFRN, 1999. In fact the argument that it is the Constitution itself that gives the leeway for the Nigerian National Assembly to, if they so decide, lay off the non-justiciable clause and throw it into the trash can holds no water because by legislating on all the provisions of Chapter Two using the force of law making would impoverish the non-justiciable clause. Therefore, the above clause exists at the mercy of the National Assembly. The finding of this article is that the clause exists as a legal mirage that can vanish on the approach of the National Assembly to the scene where the clause once held sway. This scenario paints a visible picture of the need to directly make the non-justiciable Chapter of the CFRN, 1999, as amended, justiciable through an amendment of the Constitution.
\end{abstract}

\section{Introduction}

A policy is a guide to the achievement of an objective. By constitutional policy, we mean the principles and objectives set out in the Constitution of the Federal Republic of Nigeria of 1999 (CFRN 1999) which act as a guide to achieving governmental objectives. A government without a guide is like an aircraft without a compass. In the words of Oguntade (JSC), the Constitution is the very foundation and structure upon which the existence of all organs of governance is hinged ${ }^{1}$. The arms of government have a valid constitutional legitimacy when they are not only recognised by a constitution but are duly regulated by the constitution in terms of the structure, scope of their powers and matters relating to the office holders qualification, election, selection or tenure. It is to be noted that the CFRN, 1999 has generally prescribed principles which are binding on all organs of government and these principles constitute the policy of government in Nigeria ${ }^{2}$. In line with the above submission, the CFRN, 1999 provides that, "It shall be the duty and responsibility of all organs of government and all authorities and persons, exercising legislative, executive or judicial powers, to conform to, observe and apply the provisions of this Chapter of the Constitution".

The duty of every arm of government in Nigeria in relation to the Chapter Two of the CFRN, 1999 which deals with the constitutional policy of governance is limited to conformity with, observance and application of the policies in administrative, legislate and judicial circles. However, it is doubtful whether the phrase, "the duty and responsibility of all organs of government" truly intend to make all organs of government to bear the responsibility of failing to comply, observe or apply the provisions of Chapter Two of the CFRN, 1999. The premise on which this assertion is based is the principle of non-justiceability of the Chapter ${ }^{3}$. A government that cannot be held responsible for any form of failure to perform its constitutional obligations cannot be said to bear any responsibility in relation to its obligations to the people because of the nonjusticeability of the obligations ${ }^{4}$.

In A. G. Ondo v. A. G. Federation ${ }^{5}$, the Supreme Court held, inter alia, that courts cannot enforce any of the provisions of Chapter II of the constitution until the National Assembly has enacted specific laws for their enforcement, as has been done in respect of section $15(5)^{6}$ of the 1999 ct, 2000. According to the Supreme Court, those objectives and principles that serve as the constitutional policy of governance remain mere declarations which cannot be enforced by legal process but would be seen as a failure of duty and responsibility

\footnotetext{
*G. N. Okeke, LL.M; B.L; PhD, Faculty of Law, Nnamdi Azikiwe University, Awka, Anambra, Nigeria and Chika Okeke, LL.B, B.L, Legal Practitioner.

${ }^{1}$ See the Governor of Kwara State \& anor. v.Alhaji Issa Ojibara \& 6 ors (2006) NSCQR Vol. $28,101$.

${ }^{2}$ See sections 13,14,15,16,17,18,19,20,21,22,23 and 24, CFRN, 1999.

${ }^{3}$ See s.13.

${ }^{4}$ S.6(6)(0), CFRN, 1999.

5 -(2002) 9 NWLR (Pt 772), 222

${ }^{6}$ S.15(5) CFRN 1999 provides that the state shall abolish all corrupt practices and abuse of power.
} 
of state organs if they acted in clear disregard of them. The court went further to maintain that the Directive Principles (or some of them) can be made justiceable by legislation.

\section{The Nature and Scope of the Constitutional Policy on Governance in Nigeria}

The nature of the policy is such that gives the government of the Federal Republic of Nigeria a focus. The element of focus in governmental affairs is an essential one. A person who is not focused in the obligations that he is assigned to carry out would be distracted from the main objective of carrying out the obligations and begins to chase shadows. Shadow chasing of governments is a curse to the people in a state or community because such people would have a name that they are being governed but in the actual practice the government would be virtually dead and of little or no assistance to the people in terms of provision of social amenities and an appreciable standard of living and the promotion of justice, liberty and security. Governments are meant to provide a leading guide to the people's destination by means of creating a vision on how to get to the destination and implementing goals that will get the objective realised. The CFRN 1999 as by way of provision of the Fundamental Objectives And Directive Principles of State Policy foisted on the Government of the Federal Republic of Nigeria structural guidelines relating to how to govern or rule well, the people of the nation, Nigeria. The guidelines on which the policy of government should be built upon are contained in the CFRN, $1999^{7}$. They are limited to fundamental obligations of the Government ${ }^{8}$, the Government and the people ${ }^{9}$, political objectives ${ }^{10}$, Economic objectives ${ }^{11}$, Social objectives ${ }^{12}$, Educational objectives ${ }^{13}$, Foreign policy objectives $^{14}$, Environmental objectives ${ }^{15}$, Directives on Nigerian cultures ${ }^{16}$, obligations of the mass media ${ }^{17}$, National ethics ${ }^{18}$ and Duties of the citizen ${ }^{19}$. These objectives and principles form the bedrock of the policy of the Nigerian Government. It is a notable fact that government in every modern democracy is divided into three segments: the legislature, the executive and the judiciary. The CFRN, 1999 in a reflection of this governmental structure provides the constitutional template for the smooth operation of the structure of government in Nigeria. $^{20}$

In Alhaji Abdullahi Maccido Ahmed v. Sokoto State House of Assembly \& anor ${ }^{21}$, it was held that:

The organic structure created by Part II, Chapter 1 of both the Constitution of the Federal Republic of Nigeria, 1979 and that of 1999 are three organs of power of the Federal Republic of Nigeria. Of these powers, legislative powers are vested in the legislature at both Federal and State levels and the executive in the President and Governor at the federal and state levels respectively. Judicial power, both at the federal and state levels are vested in the courts established for the federation and the states under section 6 of the Constitution.

From the foregoing, every structure of the Nigerian Government at both federal and state levels is bound to formulate policies which are in tandem with the fundamental Objectives and Directive Principles of State Policy. Policy formulation is important in the affairs of government in its bid to deliver to the people the dividends of good governance. Each structure of government though separate from the other as envisaged under the doctrine of separation of power undertakes to give effect to the constitutional policy without interference from the other. In Ahmad v. Sokoto State ${ }^{22}$, it was further held that separation of powers has three implications:

(a) that the same persons should not be part of more than one of these arms or divisions of government;

(b) that one branch should not dominate or control another arm. This is particularly important in the relationship between the executive and the courts;

(c) that one branch should not attempt to exercise the function of the other; for example, a President, however powerful ought not to make laws or indeed act except in execution of laws made by the legislature.

\footnotetext{
${ }^{7}$ See generally chapter II, CFRN, 1999

${ }^{8}$ S. 13

${ }^{9} \mathrm{~S} .14$

${ }^{10} \mathrm{~S} .15$

${ }^{11} \mathrm{~S} .16$

${ }^{12} \mathrm{~S} .17$

${ }^{13} \mathrm{~S} .18$

${ }^{14} \mathrm{~S} .19$

${ }^{15}$ S. 20

${ }^{16} \mathrm{~S} .21$

${ }^{17} \mathrm{~S} .22$

${ }^{18} \mathrm{~S} .23$

${ }^{19} \mathrm{~S} .24$

${ }^{20}$ See sections 4,5 and 6 CFRN, 1999 (as amended).

21 (2002) 15 NWLR (Pt 791), 539.

22 Supra
} 
The above decision reveals that the legislature, executive and the judiciary work independently. This independence of operation is not without the guide of the law. The CFRN, 1999 (as amended) being the basic law in Nigeria in its guidance of the Government of Nigeria has provided the objectives and principles that should form the basic policy regulating the conduct of legislative, executive and judicial affairs. In other words, all activities of these three arms of government are to be guided by the policy. Legislative acts resulting in the passage of laws are guided by the policy and the laws made in the form of Acts and Laws by the legislature in Nigeria must be such that embody this policy. In the same vein, executive acts are to be founded on the policy of the Nigerian governance. Executive acts that are bereft of the flavour of this policy should be rendered unfit for the people and questionable as to why the deviation from a standard policy that is in all its ramifications people-oriented. Furthermore, judicial pronouncements and decisions which run counter to the policy would be anti-progressive. This position on the judicial aspect of compliance to the policy does not mean that the judiciary should be biased in its adjudicatory activities. What the position projects is the awareness that the policy should guide the judiciary in its interpretative obligation especially in its use of modes of interpretation of statutes. Adapting such an approach would help promote the cause of justice in Nigeria.

Apart from the Government of Nigeria, individuals are to some extent bound by the Fundamental Objectives and Directives Principles of State Policy. This does not mean that individuals would be part of government automatically; it rather means that individuals would endeavour to foster the laudable policy in their ideals and pursuits by cooperating with the government in a kind of government people partnership. In other words, individuals should not adopt a kind of "I don't care" attitude to the realisation of the constitutional policy.

\section{Using Legislation to Make the Non-Justicial Chapter II Justiciable: A Material Contradiction}

A legislation is any law that is made by the legislature. A constitution is a form of legislation, but it is legislation sui generis, as it is a legislation from which other legislation derives their validity. A piece of legislation or any part of it is said to be non-justiciable when it cannot be positively enforced by courts within a particular jurisdiction. Ideally, all the provisions of a constitution ought to justiciabl and enforceable, but it is not all the provision of the CFRN 1999 that are justiciciabl and enforceable. This is one of the peculiarities of the Constitution. Chapter II of the 1999 constitution of the federal republic of Nigeria is rendered non justiciable by section 6 (6) (c) which provides thus:

The judicial power vested in accordance with the foregoing provisions of this section shall not, except as otherwise provide by this constitution, extend to any issue or question as to whether any act or omission by any authority or person as to whether any law or any judicial decision is in conformity with the Fundamental Objectives and Directive Principles of State Policy set out in Chapter 11 of this constitution.

The non-justiciable status of chapter 11 of the constitution had been judicially confirmed in many cases, for example, in the Archbishop Anthony Okogie v. AG Lagos State ${ }^{23}$, it was held that:

while Section 13 of the Constitution makes it a duty and responsibility of the judiciary among other organs of government to conform to and apply the provisions of Chapter 11, section 6 (6) (c) of the same constitution make it clear that no court has jurisdiction to pronounce any decision as to whether any organ of government has acted or is acting in conformity with the Fundamental Objectives and Directive Principles of State Policy. It is clear therefore that section 13 has not made chapter 11 of the Constitution justiciable.

The provisions of chapter II of the constitution is merely declaratory hence in the case of AG Ondo $V$.AG Federation $^{24}$, the Supreme Court held that those Objectives and Principles provided for under chapter II of the constitution remain mere declarations. In view of the foregoing, it is rather obvious that chapter II of the Constitution is non-justiciable, but there are ways by which Chapter II of the constit\#ution can be made justiciable and these are contained in the very section 6 (6) (c) that made chapter II of the Constitution nonjusticiable. Thus, in the case of Federal Republic of Nigeria V. Aneche \& 3 ors,$^{25}$ Niki Tobi (JSC) observed as follows:

In my humble view section 6 (6) (c) of the Constitution is neither total nor sacrosanct as the subsection provides a leeway by the use of the words "except as otherwise provides by this Constitution. This mean that if the Constitution otherwise provides in another section, which makes a section or sections of Chapter 11 jsuticiable, it will be so interpreted by the courts."

\footnotetext{
${ }^{23}$ (1981) 2 NCLR 337 at 350.

${ }^{24}$ (2002) 9 NWLR (part 772) p.22.

${ }^{25}$ (2004) I SCM P. 36 at 78.
} 
There are two ways by which the provision of the Chapter Two of the constitution can be made justiciable in the light of the exception contained in section 6 (6) (c) of the Constitution. First, where the constitution in its justiciable sections directed that a particular section of Chapter II of the Constitution shall be complied with in carrying out the provisions of that section of the Constitution. For example, Section 147(3) of the Constitution provides that "any appointment under sub-section (2) of this section by the President shall be in conformity with the provisions of section 14(3) of this constitution." Also by section 197(3) of the Constitution, "in appointing the Chairman and members of boards and governing bodies of statutory corporations and companies in which the Government of the State has controlling shares or interests and councils of Universities, colleges and other institutions of higher learning, the Governor shall conform with the provisions of section 14 (4) of this Constitution". It follows that while carrying out the provisions of Sections 147(3) and 197(3) of the Constitution, compliance with sections 14(3) and 14 (4) of this constitution becomes mandatory, thus justiciable.

The second way is where the Constitution in its justiciable sections empowers the National Assembly to implement the provisions of the Chapter II of the Constitution vie legislation. One example of this is items 60 of the Exclusive Legislative List under Part 1 of the Second Schedule to CFRN, 1999 that empowers the National Assembly to make laws with respect to "the establishment and regulation of authorities for the Federation or any part thereof... to promote and enforce the observance of the Fundamental Objectives and Directive Principle contained in this Constitution...." Commenting on the above item 60 (a), Justice Mohammed L. Uwais, CJN (as he then was), observed that "item 60 of the Exclusive Legislative List of the Constitution of the Federal Republish of Nigeria specifically empowers the National Assembly to establish and regulate authorities for the Federation to promote and enforce the observance of the Fundamental Objectives and Directive Principles, and to prescribe minimum standards of education at all levels, amongst others. The breathtaking possibilities created by this provision have sadly been obscured and negated by non-observance. This is definitely one avenue that could be meaningfully exploited by our legislature to assure the betterment of the lives of the masses of Nigeria...."26

Moreover, Obilade stated that "it is clear therefore, that although section 15 (5) of the Constitution is, in general not justiciable, as soon as the National Assembly exercises its power under section 4 the Constitution with respect to item 60 (a) of the Exclusive Legislative List, the provisions of section 15(5) of the Constitution becomes justiciable." 27 Also, in the case of $A G$ Ondo v. AG Federation ${ }^{28}$, the Supreme Court held that court cannot enforce any of the provisions of the Chapter II of the Constitution until the National Assembly has enacted specific act as it is done with respect to Section 15(5) of 1999 Constitution of the Federal Republic of Nigeria which provides that state shall abolish all corrupt practices and abuse of power. In the same vein, in the Indian case of Mangru V. Commissioner of Budge municipality", it was held that "the Directive Principles are required to be implemented by legislation, and so long as there is law carrying out the policy laid down in a Directive principle, neither the state nor an individual can violate any existing law or legal right under colour of following a directive."

It is this practice of using legislation to modify the provisions of the constitution, i.e Chapter II of the Constitution that we are set out to examine in this paper. This is very important to us because it generates material contradiction vis-à-vis all known constitutional concepts. It is indeed a strange legal practice to use legislation to modify the provisions of a constitution because it is generally believed that constitution is the "basic norm from which other laws within a legal system derive their validity" 30 and therefore, is the supreme law of any legal system. Thus, any standard constitution must necessarily contain the Supremacy Clause. The supremacy clause of the 1999 constitution of the Federal Republic of Nigeria is contained in its section 1 (3) which provides thus: if any other law is inconsistence with the provisions of this constitution, this constitution shall prevail, and that other law shall to the extent of the inconsistency be void.

The supremacy clause does not mean that the provisions of a constitution cannot be altered or modified, what it means is that constitution shall be altered by altering the constitution itself and not through the instrumentality of an ordinary legislation. Again any standard constitution must contain the terms and manners

\footnotetext{
${ }^{26}$ M.L Uwais 'Fundamental Objectives and Directive Principles of State Policy: Possibility and prospect" in C.C. Nweze, ed, Justice in the Judicial Process (Essay in Honour of Honourable Justice Eugene Uba Ezonu, JCA, Chapter 5, at P. 179.)

${ }^{27}$ A.O. Obilade, " contemporary issues in the Administration of Justice: Essay in Honour of Justice Atinuke Ige, P. 127 Culled from Federal Republic of Nigeria V. Anache (Supra).
}

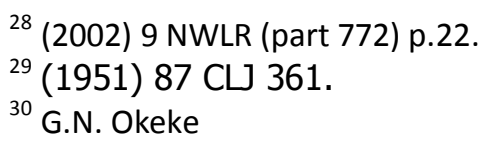


through which it can be amended. Section 9 of the 1999 Constitution of the Federal Republic of Nigeria contains the mode of altering the provisions of the constitution. Granted that most provisions of Chapter II of the CFRN, 1999 need to be made justiciable and enforceable, it appears to us that the better way of doing this is by amending the constitution itself, and not by means of ordinary legislation as this will puncture the constitutional ego of the Constitution of the Federal Republic of Nigeria, 1999.

\section{Responsibility and Non-Justiciability of the Of Chapter II of the 1999 Constitution of the Federal Republic of Nigeria, As Amended}

It is pertinent to observe here that section 13 in Chapter Two of the CFRN, 1999 is not applicable only to the organs of government or those exercising the legislative, executive and judicial powers, but to every institution. Hence in the case of $A G$ Ondo v. AG Federation, ${ }^{31}$ the Supreme Court noted thus:

It has been argued that the Fundamental Objectives and Directive Principles of State Policy are meant for authorities that exercise legislative, executive and judicial power only, and therefore any enactment to enforce their observance can apply only to such persons in authority and should not be extended to private persons, companies or private organizations. This may well be so, if narrow interpretation is to be given to the provisions, but it must be remembered that we are here concerned not with the interpretation of a statute but the constitution which is our organic law or grundnorm. Any narrow interpretation of its provision will do violence to it and will fail to achieve the goal set by the Constitution.

A literal interpretation of the above section 13 may mean that those exercising legislative, executive and judicial powers are obliged to conform, observe and apply the provisions of Chapter II. However, a general reading of the said section 13 with section 6 (6) (c) will leave no one in doubt that the drafters of the Constitution intended Chapter II of the Constitution to be non-justiciable. In reality, section 13 created responsibility without liability. A government that cannot be liable for its failure to carry out its constitutional obligations cannot be said to bear any responsibility. Such government cannot be accountable to the people who are the ultimate sovereign in a democratic system of government which is purportedly in practice in Nigeria. Section 13 is an apparent publicity stunt by the makers of the constitution to attract the applause of the people even though they know that what is given by sections 13 to 24 , which contain the national ideals without which there can be no meaning national development, is taken away by section 6 (6) (c).

This approbating and reprobating stance of the 1999 constitution of the federal republic of Nigeria with respect to Chapter II of the Constitution is a key to irresponsible governance because. It is against this backdrop that men and women of goodwill from various quarters are calling for a constitutional amendment which will make Chapter II of the Constitution justiciable. While we are looking forward with hope towards the time when this clarion calls will be hearkened to by our legislature, our judiciary must rise up to the occasion like her counterpart in other jurisdictions through judicial activism. This is the current trend in India, Ghana and South Africa that have provisions in their respective constitutions similar to Chapter II of the CFRN, 1999.

In the Indian case of Olga Tellis \& 2 ors $v$. Bombay Municipal Corporation \& ors,$^{32}$ one of the issues brought for determination before the Supreme Court was 'whether the forceful eviction and demolition of the petitioners' pavement dwelling, which affected their means of livelihood amounted to an infraction of their constitutionally guaranteed right to life. The Indian Supreme Court held that right to life includes the right to livelihood, thereby elevating the economic and social objectives of their Directive Principles to enforceable rights.

In Ghana, the Directive Principles of the State Policy are not expressly declared non-justiciable by the 1992 Constitution of Ghana. However, it had always been treated as non-justiciable by the Ghananian courts as noted in the case of The New Patriotic Party v. Attorney General. ${ }^{33}$ It is to be noted that the above position is no longer the position in Ghana because in the recent Supreme Court decision in Ghana Lotto operators Association v. National Lotteries Authority, ${ }^{34}$ it was held that all the provisions in the Constitution were justiciable because it contained the most important rule on political governance save such provisions as are expressly excluded in the Constitution. Those principle were held to be justiciable even though the original intention of the dafting committee was that they would not be justiciable because such intention did not appear in the Constitution of Ghana.

\footnotetext{
${ }^{31}$ Supra.

${ }^{32}$ (2007) CHR 236, (1987) LRC (const.) 351.

${ }^{33}$ (1996-7) SC Chana LR 728 at 745.
}

${ }^{34}(2007-8) 2$ SCGLR 
In the South African case of Government of Republic of South Africa v. Grootboom, ${ }^{35}$ it was held that, "there can be no doubt that human dignity, freedom and equality, the foundation value of our society, are denied those who have no food, clothing or shelter. Affording socio-economic rights to all people therefore enables them to enjoy the other rights enshrined in the chapter $2 . "$

From the foregoing, we have seen that the judiciary has enormous responsibility in ensuring responsible governance in Nigeria. little wonders a legal luminary, Late Dr. Akinola Aguda observed that the courts must permit themselves to be guided by the Fundamental Objectives and Directive Principles of State Policy contained in the Constitution, in their arduous task of interpreting our laws and constitutions. The foregoing point was also made in the case of Damish V. Speaker House of Assembly of Benue State, ${ }^{36}$ where it was held that even though the rights contained in Chapter II are not justiciable, they contain guidelines as to what the courts should do when confronted with the problem of interpretation of the constitution.

\section{Conclusion}

The Nigerian Federation is fundamentally governed according to the basic law of the land, that is, the Constitution of the Federal Republic of Nigeria, 1999, as amended. The provisions in Chapter Two of the said Constitution are intended by it to be non-justiceable. However, instead of an express and direct provision making the Chapter justiciable, it provides for an indirect mode of making any of the sections of the Chapter justiciable. It permits the legislature to enact a law making any of the sections justiciable. This indeed adds a multiplier effect to the function of the legislative arm of government in Nigeria because it has gone a long way to multiply the law making function of the legislature and inadvertently makes legislative supremacy over the Constitution of the Federal Republic of Nigeria, 1999, as amended a present reality.

\footnotetext{
${ }^{35}$ (2001) 36 WRN 137 at 162-163

${ }^{36}$ (1983) NCLR 625
} 